\title{
sciendo

\section{Life Cycle Cost Analysis of Biogas Production from Cerathophyllum demersum, Fucus vesiculosus and Ulva intestinalis in Latvian Conditions}

\author{
Laura PASTARE ${ }^{1 *}$, Francesco ROMAGNOLI $^{2}$ \\ ${ }^{1,2}$ Institute of Energy Systems and Environment, Riga Technical University, \\ Azenes iela 12/1, Riga, LV-1048, Latvia
}

\begin{abstract}
Life cycle costs of co-digestion plant of cattle farm manure and locally available freshwater macrophyte $C$. demersum, marine brown algae $F$. vesiculosus, and marine green algae $U$. intestinalis; ratio 5:1) are analysed based on Latvian climatic and economic conditions. Biomass collection from nature and pre-treatment of biomass, biogas production, biogas treatment and utilization in combined heat and power plant are included in the boundaries. The weak points of scenarios are large capital investments, electricity sale price (and the application of feed-in tariff). As naturally grown algae and macrophytes are used, they are also sensitive to weather conditions each year as available amounts of biomass might change and decrease. Net Present Value is positive only for $C$. demersum with Internal Rate of Return of $-14 \%$ and Discounted Payback Period of 11 years.
\end{abstract}

Keywords - Algae; biogas; LCCA; Life Cycle Cost Analysis

\section{INTRODUCTION}

As the carbon-intensive activities are still posing different risks to the environment and is threatening sustainability, the search for alternative fuel sources has become an important topic for world leaders as well as regular citizens. In search of the best solution (application, costs, availability, etc.) many different alternative energy production technologies and fuels are examined more closely [1]. Biogas as a replacement fuel offers easy application in already existing infrastructure for natural gas use. It can be cleaned to standards of natural gas and injected into existing natural gas streams as well as directly used in the same energy generation applications. Biogas production process itself is also versatile as different set-ups can be used based on type of biomass available as well as specific climatic conditions. As biogas can be produced from a variety of different biomasses it is very versatile and could be used globally with ease, as the technological advancement is faster as compared to other similar technologies [2].

The search for the best biomass for biogas production is still ongoing as there are many aspects to be taken into account. First generation biofuels (rapeseed, wheat, etc.) were food crops that raised ethical questions of food sources being used for energy production as well as using fertile arable lands. Second-generation fuels tried to pass by the food vs. fuel debate by using non-food crops (straw, wood, crop waste). Both of these generations struggled with net energy gains - using more energy for the production process than actually producing.

\footnotetext{
* Corresponding author.

E-mail address: laura.pastare@gmail.com
} 
Third generation fuels have improved the weak spots of previous generations, as algae do not require arable lands and have fast growing rates [3]. It is considered as viable input for biogas production [4], [5]. As algae species availability differs from region to region, deeper analysis should be carried out for each region separately to determine the best solutions of real life, large-scale applications. Despite the promising potential, algae use is still not commercialized, as many constraining factors exist [6]. Thus, deeper examination and solutions should be found.

Algae can be either grown in pond systems (open or closed) or collected directly from nature. Cultivating algae adds another step of costs and limitations to the whole process. Collection from nature, even though unreliable, in the long term offers an opportunity of reduced costs and possible environmental benefits. Depending on water body proximity, their condition and other restrictions (protected zone limitations) it is important to collect a choice of species. All species of algae have different growing and reproducing conditions as well as their biogas yields, volatile solids, totals solids are different. A preliminary analysis of available species in each region as well as experimental research is needed to find the best available opportunities [6].

Study by Balina et al. [5] determined three potential marine algae species available and usable for Latvian conditions (Fucus vesiculosus, Furcellaria lumbricalis and Ulva intestinalis). As $F$. vesiculosus and $U$. intestinalis have been reported to regularly be washed out on shore along Latvian coastline [5]. They are chosen to be evaluated in more details in this study. Study by Pastare et al. [7] determined that Cerathophyllum demersum is a potentially viable algae species used for biomass production due to its availability as well as reported biogas yields. Further experimental analysis of locally collected algae and their biochemical methane potential have already been performed [5], [7]-[9]. Based on those results, all species can be considered usable for biogas production. The aim of this study is to perform a full life cycle costs analysis for the three chosen algae species (F. vesiculosus, $U$. intestinalis and $C$. demersum) in order to compare them and find the most suitable species for biogas production locally. Environmental aspects as well as aspects relating to licensing and protection limitations are not considered at this time.

\section{DESCRIPTION OF SCENARIOS}

Within this study 3 different scenarios for algae use for biogas production and use in combined heat and power (CHP) units are compared. Based on previous studies [5], [7] the selected species are Cerathophyllum demersum (freshwater macrophyte), Fucus vesiculosus (marine brown algae) and Ulva intestinalis (marine green algae), see Fig. 1. Even though C. demersum is a macrophyte, based on the characteristics (growing rates, digestion rate and availability) it is analysed together with algae as part of this study. 


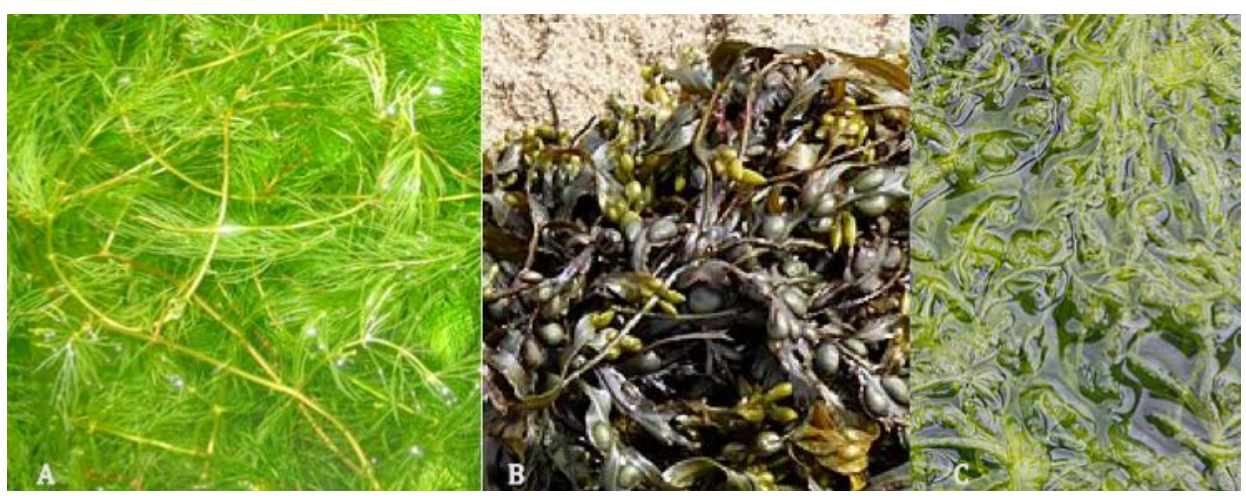

Fig. 1. Species selected for study: a) Cerathophyllum demersum; b) Fucus vesiculosus; c) Ulva intestinalis.

In all three scenarios the algae are naturally grown and collected either directly from water bodies (in case of $C$. demersum - from lakes) or from shores (in case of $F$. vesiculosus and $U$. intestinalis - from shores of the Baltic Sea and Gulf of Riga). The collection is carried out only after the bloom period, usually starting July until November, when the water bodies start freezing over or all of the available washed-out algae has been collected. A boat and a comb-type attachment (attachment that catches the grown algae itself) are leased for collecting $C$. demersum for 150 days per year on average. Both marine algae species $(F$. vesiculosus and $U$. intestinalis) are collected using a small tractor and a comb-type attachment.

In all scenarios, the average distance from algae collection to the site is $100 \mathrm{~km}$. After collection the algae are transported to site, where it is stored in $4{ }^{\circ} \mathrm{C}$ before being treated and used for biogas production. Algae are stored in a cooled temperature to avoid biomass degradation. The temperature in the storage unit is maintained only in the summertime and partially throughout spring and autumn when needed as the average temperature in Latvia during the months of November until March has been around or lower than $4{ }^{\circ} \mathrm{C}$ in the last 5 years [10], [11].

The algae are stored in the storage unit until needed for the biogas production process. Pre-treatment of algae is carried out shortly before adding it to the digestion tank. Pre-treatment includes washing of salt and debris for marine algae species (F. vesiculosus and $U$. intestinalis). Washing out is carried out in water tanks with sieves using freshwater as a cleaning medium. The algae are submerged in the water, letting the salt dissolve in the water, as well as it is manually stirred to help remove sand and debris. After algae have been submerged in the water, the tank is drained, leaving the algae on sieves. Washing of salt and debris improves the overall digestibility of algae as salt is an inhibiting factor for methanogenic bacteria [12].

As part of pre-treatment, shredding is also carried out in all scenarios. A twin shaft shredder is used. Shredding improves the digestion rate as well makes it easier to feed-in the feedstock [9].

Algae are co-digested with cattle farm manure (ratio 1:5 based on VS) to improve the overall feasibility and digestion rate. See Table 1 for details of anaerobic digestion details per algae species. The inputs are based on previous experiments [7]-[9] as well as literature analysis [12], [13]. 
TABLE 1. BIOMASS PARAMETERS FOR BIOGAS PRODUCTION

\begin{tabular}{lllll}
\hline Biomass & C. demersum & F. vesiculosus & U. intestinalis & Cattle farm manure \\
\hline Biogas yield, & 405.3 & 81.1 & 92.1 & 300 \\
1 CH 4 /kg VS & & & & \\
VS, \% & 78.3 & 78.5 & 78.5 & 79.0 \\
Moisture, \% & 94.9 & 82.2 & 78.7 & 85.0 \\
TS, $\%$ & 5.1 & 17.8 & 21.3 & 15.0 \\
\hline
\end{tabular}

As algae are growing naturally and are collected directly from nature, there are limits in the amounts available each year for collection. The limit is assumed based on the average washed out algae load size per meter of coastline per year $(25 \mathrm{~kg} / \mathrm{m})$ and the length of the coastline $(494 \mathrm{~km})$ [14]. Based on that information, the biogas yields and the chosen algae-manure ratio a digestion tank with a capacity of $1500 \mathrm{~m}^{3}$ and a CHP unit with $250 \mathrm{~kW}$ electrical capacity are chosen. As each of the algae has a different biogas yield, volatile solids and total solids content, the amount of feedstock needed to operate the CHP unit to get the same outcome differs (Table 2).

TABLE 2. OPERATIONAL INPUTS FOR SCENARIOS

\begin{tabular}{lllllll}
\hline & C. demersum & Manure & F. vesiculosus & Manure & U. intestinalis & Manure \\
\hline $\begin{array}{l}\text { Inputs, t/year } \\
\begin{array}{l}\text { Methane produced, } \\
\mathrm{m}^{3} / \text { year }\end{array}\end{array}$ & 6328 & 14432 & 9055 & 14432 & 6663 & 14432 \\
$\begin{array}{l}\text { Methane produced } \\
\text { in total, m/year }\end{array}$ & 615663 & 513052 & 102610 & 513052 & 102610 & 513052 \\
$\begin{array}{l}\text { Electricity produced } \\
\text { in total, MWh/year }\end{array}$ & 2190 & & 615663 & & 615663 & \\
$\begin{array}{l}\text { Heat produced in } \\
\text { total, MWh/year }\end{array}$ & 3942 & 2190 & & 2190 & \\
\hline
\end{tabular}

All calculations are based on generating $2190 \mathrm{MWh}$ electricity and $3942 \mathrm{MWh}$ heat per year.

\section{DESCRIPTION OF COSTS}

Life cycle costs analysis is a cost-effectiveness approach and requires detailed inventory (or estimations) of overall costs as well as benefits [15]. The 4 main phases of any project are - acquisition and design phase, construction phase, operation, maintenance and repair phase and residual phase [16]. Residual phase is not considered in this study.

The main relevant costs are design \& licensing, capital investments and O\&M (operation and maintenance). Design and licensing costs are estimated to be $3 \%$ of total capital investments [17].

The capital investment costs are the sum of costs of equipment for algae collection and transportation (small tractor with an attachment), storage units for feedstock and digestate, container units for pre-treatment, pre-treatment equipment (washing tank, shredder), biogas digestion plant (reactor, pumps and mixers, network connections, feeding system, measurement and control system, heat system), biogas treatment equipment (compressor, 
condensator), CHP plant (co-generation engine, input ventilator, cooler, emergency cooler). Land acquisition costs are not included.

Operational and maintenance costs are directly based on the scenarios and can be divided into 2 major groups - collection and transportation and biogas production (Fig. 2).

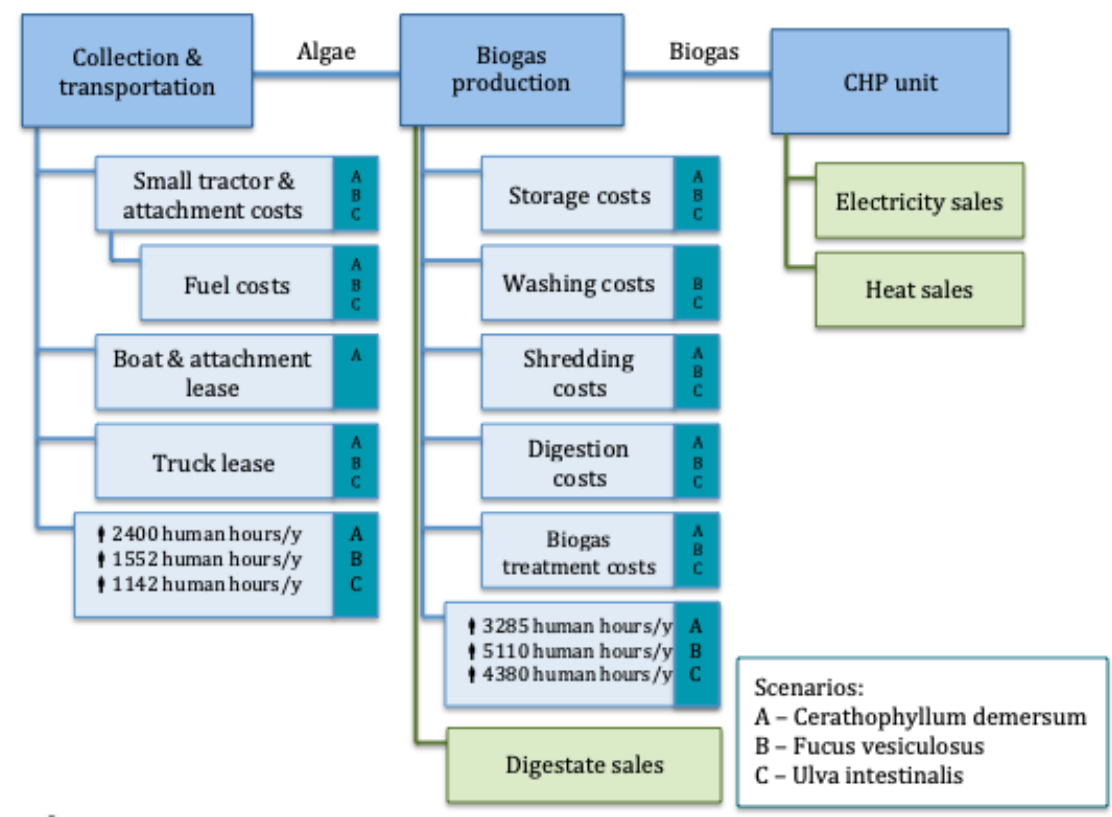

Fig. 2. Main operational costs.

Operation and maintenance include labour for operating algae collection machinery, overseeing pre-treatment, digestion, treatment and CHP plant operations. Consumables include diesel for collection transportation, electricity for cooling storage units, water and wastewater costs for pre-treatment, and electricity for pre-treatment. Lease includes water transportation lease for algae collection and land transportation lease for moving algae to site. Maintenance and replacement of other goods in cash flow are presented in O\&M position. Digestion, treatment and CHP unit electricity and heat needs are included in the parasitic electricity consumption. Maintenance costs are assumed as $2 \%$ of capital investments [18], [19].

Depreciation depends on the estimated life span for each item (linear method). Other costs include activities like accounting, consultations and alike. Insurance costs are $0.05 \%$ of capital investment [17]. Loan is calculated as $70 \%$ of total investments. Inflation rate is $2 \%$, rate on loan is $3.5 \%$. Income tax is $15 \%$ [17]. The study period is 20 years; discount rate is $5 \%$. Post financing is $70 \%$ debt capital and $30 \%$ equity capital with a loan period of 10 years and interest rate of $3.5 \%$ [19]. See Table 3 for more detailed information of costs and revenues of scenarios. 
TABLE 3. TOTAL COSTS AND REVENUES FOR SCENARIOS

\begin{tabular}{llll}
\hline & C. demersum & F. vesiculosus & U. Intestinalis \\
\hline Capital investments, EUR & 2727750 & 2732750 & 2732750 \\
Acquisition and design, EUR & 81833 & 81983 & 81983 \\
Total investment, EUR & 2809583 & 2814733 & 2814733 \\
O\&M & & & \\
Labour, EUR/year & 32988 & 35136 & 333778 \\
Consumables, EUR/year & 803 & 78545 & 30531 \\
Lease, EUR/year & 55579 & 25871 & 58011 \\
Maintenance, EUR/year & 54555 & 54655 & 19038 \\
Depreciation, EUR/year & 168193 & 169543 & 54655 \\
Other, EUR/year & 2000 & 2000 & 169543 \\
Insurance, EUR/year & 13639 & 13664 & 13664 \\
Income from electricity, EUR/year* & 279081 & 594822 & 581491 \\
Income from electricity, EUR/year & 65561 & 384277 & 367971 \\
Income from heat, EUR/year & 150525 & 275193 & 279081 \\
Income from digestate, EUR/year & 149467 & 64648 & 65561 \\
Loan amount, EUR & 1966708 & 1970313 & 1970313 \\
PMT, EUR/year & 236479.63 & 236913.10 & 236913.10 \\
\hline With & & &
\end{tabular}

*With feed in tariff.

Revenues come from selling the excess electricity, heat and digestate. For the first 10 years of a project, electricity is sold with a feed-in tariff. In accordance with Latvian Cabinet Regulation No. 221, electricity producers upon production of electricity in cogeneration can apply for the sale of electricity within the framework of the mandatory procurement. For the first 10 years of operation, the price for electricity produced is determined based on trader electricity price, the natural gas tariff and differentiation coefficient, which depends on the electric capacity installed in a cogeneration unit [19], [20]. See Table 3 for main total costs and revenues of each scenario.

More detailed information about the inputs for LCCA can be found in Annex 1. It should be taken into account that only the major costs of projects are taken into account. All cost estimations are subject to reference. All cost estimations are made with consideration of the time value of money and currency rates. To convert prices into today's gross domestic product deflator was used as price index. Eq. (1) was used to convert past prices to price level for a specific year by using GDP deflator value for a specific year [21].

$$
\text { Price }_{\text {Specificyear }}=\frac{\text { GDPDeflator }_{\text {Specific year }}}{\text { GDPdeflator }} \text { Price }_{\text {Base year ear }} \text {, }
$$

where

Price $_{\text {Specific year }}$

Price $_{\text {Base year }}$

GDP Deflator Specific year

GDP Deflator Base year
Price level in a specific year;

Price level in a past year;

GDP deflator index in a specific year;

GDP deflator index in a past year [18]. 


\section{Methodology of LCC}

The following section presents the methodology of Life Cycle Cost Analysis (LCCA). LCCA is an economic method that uses a structured approach to address all different costs occurring during a lifetime (or a set period) of a project. It also offers an evaluation of economic consequences (costs, revenues, cash flows etc.) and monetary trade-offs. This analysis allows for comparisons of alternative scenarios to optimize the costs in a given time period. For projects needing both environmental and economic analysis, LCCA is a great tool as it can cover project stages in the same way as Life Cycle Analysis (LCA) [22]-[24].

LCCA is widely used (starting from US and EU governments, businesses, scientists etc.) due to many advantages. Main advantages are projection of relevant cash flows, time value of money taken into account, comparisons possible, can assist in decision making process and main critical costs points are easily determined. Of course, there are some constraints as well - indirect costs usually are out of boundaries, it is time consuming, lack of reliable data may lead to unreliable results and comparison with different benefits are impossible [16].

For all projects 4 main categories of costs exist - Acquisition and design costs (research, design, rent and licensing, other), Construction costs (materials, construction), Operation, maintenance and repair costs (Resources as energy, water, other consumables; Maintenance as repairs, planned maintenance and waste management; Operational as labour and others) and residual costs (Disposal costs and benefits). Depending on the type of project being analysed, the distribution of these costs can vary greatly [16]. For this study the total costs are comprised of:

1. Capital Investments;

2. Acquisition and Design;

3. Operation and Maintenance:

- Labour,

- Consumables,

- Lease,

- Maintenance,

- Depreciation,

- Other;

4. Insurance;

5. Loan.

The viability of scenarios is determined based on several economic factors like net present value (NPV), internal rate of return (IRR) and discounted payback (DPB). Used discount rate for NPV calculation is 2 per cent. NPV is the sum of discounted values in the flow until a specific reference date. NPV shows how the cash flow is affected by time. It helps determine and compare the value of an investment [25]. Discount rate is used for discounting the cash flow to the present.

Internal Rate of Return (IRR) is also used in determining the viability of a project. IRR estimates the profitability of potential investments by calculating the discount rate by which the NPV of all cash flow in a project are equal to zero. Or in other words, IRR shows the maximum value of the interest rate with which it is acceptable to borrow money for the project development. Discounted Payback measures how long recovery of initial investment will take place. These values can be used to accept or reject a certain project. IF NPV value is greater than 0 , then the project can be accepted, if it's smaller than 0 ; it should be rejected. In case of several positive NPV values, the project with the highest value should be chosen. 
In case of IRR, positive values - accept project, negative - reject. DPB should be shorter than the study period (which is 20 years) [21].

\section{RESUlts}

Cash flow is modelled based on the inputs and assumptions mentioned before. NPV, IRR and DPB values can be seen in Table 4.

TABLE 4. NPV, IRR, DPB OF SCENARIOS

\begin{tabular}{llll}
\hline & C. demersum & F. vesiculosus & U. intestinalis \\
\hline NPV & 51009 & -505683 & -219061 \\
IRR & $-14 \%$ & Undefined & $-20 \%$ \\
DPB & Year 11 & After 20 years & Year 11 \\
Evaluation & Reject & Reject & Reject \\
\hline
\end{tabular}

As it can be seen from NPV, only use of $C$. demersum, as a feedstock would give a positive cash flow in a 20-year span. Even though $U$. intestinalis discounted payback period is the same as $C$. demersum (11 years), the internal rate of return is too high to be accepted as viable. Based on this information alone - all of the projects should be rejected, as the IRR values are negative or undefined. Even with a positive NPV value, the $C$. demersum scenario would not be a good investment.

Cost structure of all scenarios can show the most critical cost positions. All costs are expressed as a percentage of total costs per year for operation of the biogas plant and CHP unit (including algae collection and pre-treatment). The yearly costs of capital goods are estimated in terms of depreciation and insurance costs. The yearly costs of other positions are estimated according to previously described inventory.

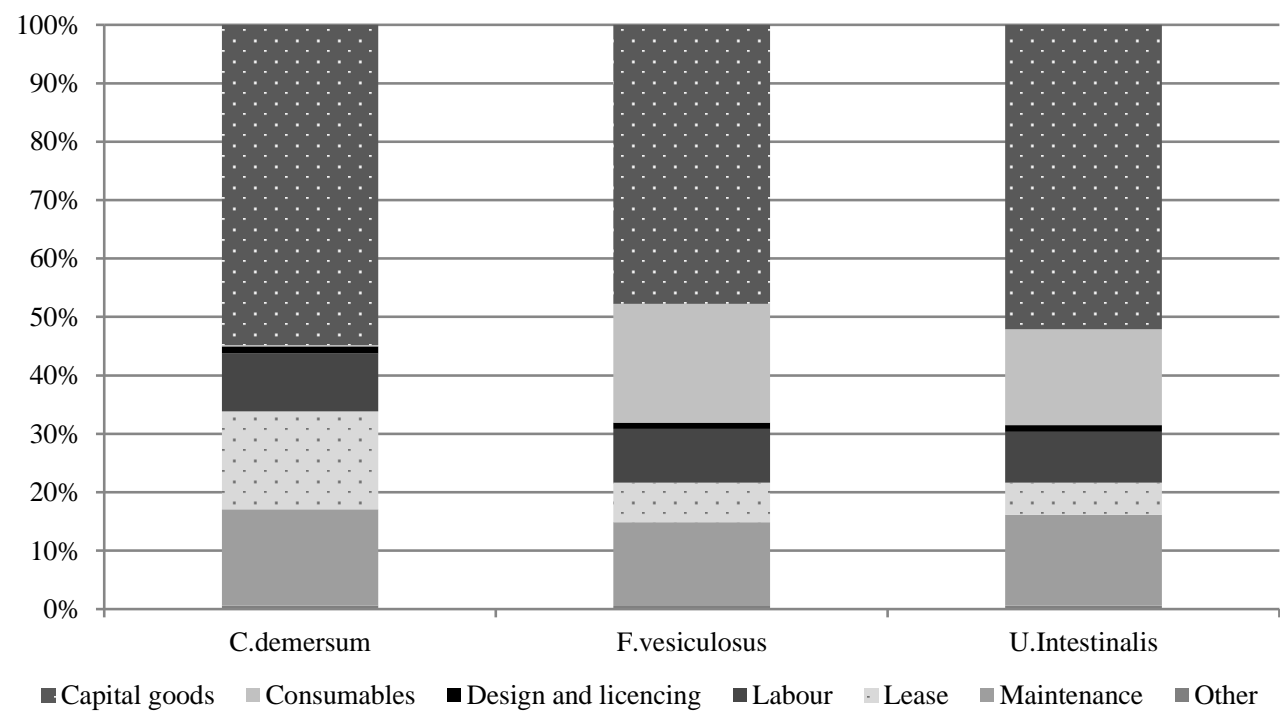

Fig. 3. Costs structure of scenarios. 
As it can be seen in Fig. 3, the most critical costs are capital goods and maintenance for all scenarios and either consumable (for $F$. vesiculosus and $U$. intestinalis) or lease (for $C$. demersum) costs. As $C$. demersum does not require washing of salt and debris, consumable costs are significantly smaller, but as it requires boat rental for extraction from water, lease costs are significantly higher. Besides, the cost structure it is important to evaluate the revenue structure (Fig. 4).

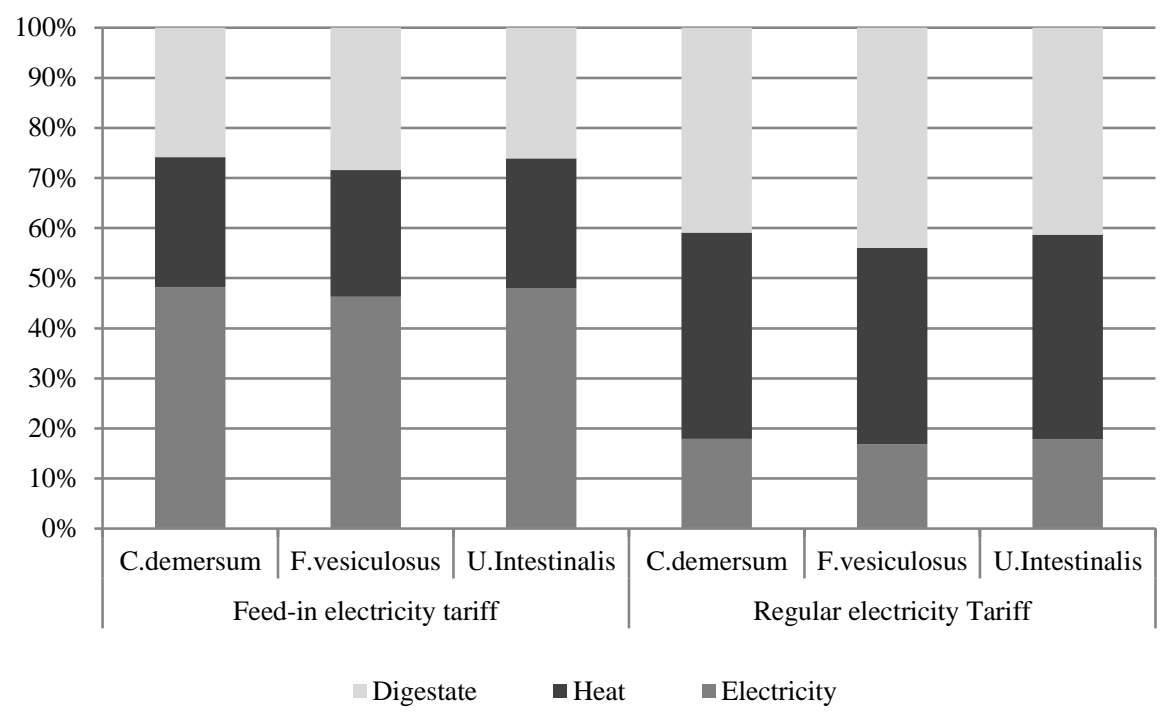

Fig. 4. Revenue structure of scenarios.

The revenue consists of selling electricity, heat and digestate. The feed-in tariff for electricity selling is a major influence on revenue, changing from $46-48 \%$ to $17-18 \%$ (with and without the feed-in tariff, accordingly). Revenue from heat and digestate makes up a similar amount from total revenues.

As there are a lot of capital investments associated with having a biogas production site and CHP unit, one of the options to cut down costs would be to sell the treated biomethane as an end product. By eliminating a big part of capital and operational costs, it is possible that, with reduced revenues, NPV, IRR and DPB would be more favourable.

By eliminating the CHP unit on site and selling the cleaned biogas to another biogas production site or CHP unit capital investments for the unit can be avoided. As no longer either electricity or heat will be produced on site, additional costs for electricity and heat use arise. It is assumed there are no additional costs for transporting the produced biogas to another site; all costs related are covered by the selling price. For each scenario, there is different break-even price for NPV (Table 5). For a positive NPV for projects the biogas-selling price is in the range of 547 to $599 \mathrm{EUR} / \mathrm{t} . \mathrm{m}^{3}$. The average natural gas sale price for end-users in year 2017 was $287 \mathrm{EUR} / \mathrm{t} . \mathrm{m}^{3}$ [23]. Without any subsidies or feed-in tariffs for biogas selling, the almost-double price is not competitive enough for a project to be viable. 
TABLE 5. NPV, IRR AND DPB FOR SCENARIOS DEPENDING ON BIOGAS SELLING PRICE

\begin{tabular}{|c|c|c|c|c|c|c|c|c|c|}
\hline \multirow{2}{*}{$\begin{array}{l}\text { Biogas } \\
\text { selling } \\
\text { price, } \\
\text { EUR/t.m }\end{array}$} & \multicolumn{3}{|l|}{ C. demersum } & \multicolumn{3}{|l|}{ F. vesiculosus } & \multicolumn{3}{|l|}{ U. intestinalis } \\
\hline & NPV, EUR & $\begin{array}{l}\text { IRR, } \\
\%\end{array}$ & $\begin{array}{l}\mathrm{DPB}, \\
\text { years }\end{array}$ & NPV, EUR & $\begin{array}{l}\text { IRR, } \\
\%\end{array}$ & $\begin{array}{l}\mathrm{DPB}, \\
\text { years }\end{array}$ & NPV, EUR & $\begin{array}{l}\text { IRR, } \\
\%\end{array}$ & $\begin{array}{l}\text { DPB, } \\
\text { years }\end{array}$ \\
\hline 287 & -2663092 & - & $>20$ & -3198554 & - & $\begin{array}{l}>20 \\
\text { years }\end{array}$ & -2940103 & - & $>20$ \\
\hline 300 & -2529699 & - & $>20$ & -3065160 & - & $\begin{array}{l}>20 \\
\text { years }\end{array}$ & -2806710 & - & $>20$ \\
\hline 400 & -1503994 & - & 11 & -2039056 & - & $>20$ & -1780605 & - & 11 \\
\hline 500 & -477490 & $-10 \%$ & 11 & -1012951 & $-13 \%$ & 11 & -754501 & $-11 \%$ & 11 \\
\hline 547 & 0 & $-7 \%$ & 11 & -530682 & $-10 \%$ & 11 & -272232 & $-8 \%$ & 11 \\
\hline 574 & 281827 & $-6 \%$ & 11 & -253634 & $-8 \%$ & 11 & 0 & $-7 \%$ & 11 \\
\hline 599 & 538353 & $-5 \%$ & 11 & 0 & $-7 \%$ & 11 & 261343 & $-6 \%$ & 11 \\
\hline 600 & 548615 & $-5 \%$ & 11 & 13153 & $-7 \%$ & 11 & 271604 & $-6 \%$ & 11 \\
\hline 700 & 1574719 & $-1 \%$ & 11 & 1039257 & $-3 \%$ & 11 & 1297708 & $-2 \%$ & 11 \\
\hline 800 & 2600823 & $1 \%$ & 2 & 2065362 & $0 \%$ & 4 & 2323812 & $1 \%$ & 2 \\
\hline 900 & 3626928 & $4 \%$ & 2 & 3091466 & $3 \%$ & 2 & 3349917 & $4 \%$ & 2 \\
\hline
\end{tabular}

Also for projects using naturally grown algae, it must be taken into account that the amounts of biomass available each year might fluctuate due to weather conditions. As the total project timeline is 20 years, it must be taken into account that during this period the general condition of water bodies might change (eutrophication, pollution) as well as legal aspects of biomass collection from nature. In order to approve a project like this, alternative plans should be considered for obtaining biomass as well as adjusting the digestion process accordingly.

\section{Conclusions}

As the study shows, based on experimental analysis of locally available algae as well as life cycle costs analysis, the use of algae for biogas production in current Latvian conditions is not viable. There are several weak points of such scenarios - the low biochemical methane potential, high investment costs, low electricity prices as well as possibly inconsistent source of biomass. In order to make algae use viable at least one of these factors should be resolved and even then, it might not be enough.

\section{ACKNOWLEDGEMENT}

This research is funded by the Latvian Council of Science, project "Integrated CO2 biofilter and microalgae biomass production technology for biogas plants using novel Stacked Modular Open Raceway Pond approach (SMORP)", project No. lzp-2018/1-0232. 


\section{ANNEX}

\begin{tabular}{|c|c|c|c|c|c|}
\hline \multirow[t]{2}{*}{ Parameter } & \multicolumn{3}{|l|}{ Value } & \multirow[t]{2}{*}{ Unit } & \multirow[t]{2}{*}{ Source } \\
\hline & C. demersum & F. vesiculosus & U. intestinalis & & \\
\hline \multicolumn{6}{|c|}{ Algae collection and transportation } \\
\hline Skid steer loader price & 17000 & 17000 & 17000 & EUR/unit & [26] \\
\hline Skid steer loader life span & 20 & 20 & 20 & Years & [26] \\
\hline $\begin{array}{l}\text { Skid steer loader } \\
\text { attachment price }\end{array}$ & 5000 & 5000 & 5000 & EUR/unit & [26] \\
\hline $\begin{array}{l}\text { Skid steer loader } \\
\text { attachment life span }\end{array}$ & 20 & 20 & 20 & Years & [26] \\
\hline $\begin{array}{l}\text { Skid steer loader daily } \\
\text { usage in base }\end{array}$ & 2 & 2 & 2 & Litres/day & Assumption \\
\hline $\begin{array}{l}\text { Skid steer loader usage for } \\
\text { collection }\end{array}$ & - & 194 & 143 & Days/year & Calculation \\
\hline $\begin{array}{l}\text { Skid steer loader diesel } \\
\text { consumption while } \\
\text { collecting }\end{array}$ & - & 10 & 10 & Litres/day & [26] \\
\hline Diesel price & 0.79 & 0.79 & 0.79 & EUR/litre & [27] \\
\hline $\begin{array}{l}\text { Boat with mechanical } \\
\text { motor and attachment lease } \\
\text { (including diesel } \\
\text { consumption) }\end{array}$ & $200+50$ & - & - & EUR/day & [28] \\
\hline $\begin{array}{l}\text { Boat with mechanical } \\
\text { motor and attachment lease }\end{array}$ & 150 & - & - & Days & Assumption \\
\hline $\begin{array}{l}\text { Truck (10 } \mathrm{t} \text { with } \\
\text { self-loader) lease }\end{array}$ & 200 & 200 & 200 & EUR/day & [29] \\
\hline Truck daily capacity & 70 & 70 & 70 & t/day & Assumption \\
\hline Truck lease & 90 & 129 & 95 & Days/year & Calculation \\
\hline $\begin{array}{l}\text { Collection labour worker } \\
\text { need }\end{array}$ & 2 & 1 & 1 & People/day & Assumption \\
\hline Days needed & 150 & 194 & 143 & Days/year & Calculation \\
\hline Hours per day worked & 8 & 8 & 8 & $\mathrm{~h} /$ day & Assumption \\
\hline Wage & 5 & 5 & 5 & $\mathrm{EUR} / \mathrm{h}$ & Assumption \\
\hline \multicolumn{6}{|l|}{ Storage } \\
\hline $\begin{array}{l}\text { Feedstock storage unit } \\
\text { price }\end{array}$ & 15000 & 15000 & 15000 & EUR/unit & [18] \\
\hline $\begin{array}{l}\text { Feedstock storage unit life } \\
\text { span }\end{array}$ & 20 & 20 & 20 & Years & [18] \\
\hline Digestate storage unit price & 7500 & 7500 & 7500 & EUR/unit & [18] \\
\hline $\begin{array}{l}\text { Digestate storage unit life } \\
\text { span }\end{array}$ & 20 & 20 & 20 & Years & [18] \\
\hline Cooling unit power & 4 & 4 & 4 & $\mathrm{~kW}$ & [18] \\
\hline $\begin{array}{l}\text { Operation hours for } \\
\text { cooling }\end{array}$ & 4320 & 4320 & 4320 & $\mathrm{~h} /$ year & [18] \\
\hline Pre-treatment & & & & & \\
\hline
\end{tabular}




\begin{tabular}{|c|c|c|c|c|c|}
\hline \multirow[t]{2}{*}{ Parameter } & \multicolumn{3}{|l|}{ Value } & \multirow[t]{2}{*}{ Unit } & \multirow[t]{2}{*}{ Source } \\
\hline & C. demersum & F. vesiculosus & U. intestinalis & & \\
\hline $\begin{array}{l}\text { Pre-treatment container } \\
\text { unit price }\end{array}$ & 75000 & 75000 & 75000 & EUR/unit & [18] \\
\hline $\begin{array}{l}\text { Pre-treatment container } \\
\text { unit life span }\end{array}$ & 20 & 20 & 20 & Years & [18] \\
\hline $\begin{array}{l}\text { Feedstock washing tank } \\
\text { price }\end{array}$ & - & 5000 & 5000 & EUR/unit & [18] \\
\hline $\begin{array}{l}\text { Feedstock washing tank } \\
\text { life span }\end{array}$ & - & 10 & 10 & Years & [18] \\
\hline $\begin{array}{l}\text { Freshwater need for } \\
\text { pre-treatment }\end{array}$ & - & 5 & 5 & $\mathrm{~m}^{3} / \mathrm{t}$ algae & Assumption \\
\hline Freshwater price & - & 0.88 & 0.88 & $\mathrm{EUR} / \mathrm{m}^{3}$ & [30] \\
\hline Effluent discharge price & - & 0.79 & 0.79 & EUR $/ \mathrm{m}^{3}$ & [30] \\
\hline Feedstock shredder price & 12000 & 12000 & 12000 & EUR/unit & [19] \\
\hline $\begin{array}{l}\text { Feedstock shredder life } \\
\text { span }\end{array}$ & 10 & 10 & 10 & Years & [19] \\
\hline Feedstock shredder power & 25 & 25 & 25 & $\mathrm{~kW}$ & [19] \\
\hline $\begin{array}{l}\text { Feedstock shredder usage } \\
\text { daily }\end{array}$ & 6 & 9 & 6 & h/day & Calculation \\
\hline $\begin{array}{l}\text { Labour worker need per } \\
\text { day }\end{array}$ & 1 & 2 & 2 & & Assumption \\
\hline Hours worked per day & 5 & $5 \cdot 2$ & $4 \cdot 2$ & $\mathrm{~h} /$ day & Assumption \\
\hline Labour worker wage & 3.5 & 3.5 & 3.5 & EUR/hour & Assumption \\
\hline \multicolumn{6}{|c|}{ Digestion - biogas treatment - CHP plant } \\
\hline Digestion tank capacity & 1500 & 1500 & 1500 & $\mathrm{~m}^{3}$ & Assumption \\
\hline Algae input & 6328 & 9055 & 6663 & $\mathrm{~T}$ ww/year & Calculations \\
\hline Manure input & 14432 & 14432 & 14432 & $\mathrm{~T}$ ww/year & Calculation \\
\hline Algae: Manure ratio & $1: 5$ & $1: 5$ & $1: 5$ & - & Assumption \\
\hline Digestion reactor & 1937500 & 1937500 & 1937500 & EUR/unit & $\begin{array}{l}{[19]} \\
\text { (adapted) }\end{array}$ \\
\hline Digestion reactor life span & 20 & 20 & 20 & Years & [19] \\
\hline Pump and mixer & 56250 & 56250 & 56250 & EUR/unit & $\begin{array}{l}{[16]} \\
\text { (adapted) }\end{array}$ \\
\hline Pump and mixer life span & 10 & 10 & 10 & Years & [19] \\
\hline Network connections & 25000 & 25000 & 25000 & EUR/unit & $\begin{array}{l}{[19]} \\
\text { (adapted) }\end{array}$ \\
\hline $\begin{array}{l}\text { Network connections life } \\
\text { span }\end{array}$ & 20 & 20 & 20 & Years & [19] \\
\hline Feeding system & 50000 & 50000 & 50000 & EUR/unit & $\begin{array}{l}\text { [19] } \\
\text { (adapted) }\end{array}$ \\
\hline Feeding system life span & 7 & 7 & 7 & Years & [19] \\
\hline $\begin{array}{l}\text { Measurement and control } \\
\text { system }\end{array}$ & 18750 & 18750 & 18750 & EUR/unit & $\begin{array}{l}{[19]} \\
\text { (adapted) }\end{array}$ \\
\hline
\end{tabular}




\begin{tabular}{|c|c|c|c|c|c|}
\hline \multirow[t]{2}{*}{ Parameter } & \multicolumn{3}{|l|}{ Value } & \multirow[t]{2}{*}{ Unit } & \multirow[t]{2}{*}{ Source } \\
\hline & C. demersum & F. vesiculosus & U. intestinalis & & \\
\hline $\begin{array}{l}\text { Measurement and control } \\
\text { system life span }\end{array}$ & 10 & 10 & 10 & Years & [19] \\
\hline Heating system & 31250 & 31250 & 31250 & EUR/unit & $\begin{array}{l}{[19]} \\
\text { (adapted) }\end{array}$ \\
\hline Heating system life span & 10 & 10 & 10 & Years & [19] \\
\hline Electricity usage & \multicolumn{4}{|c|}{ Included in parasitic electricity use } & Assumption \\
\hline Heat usage & \multicolumn{4}{|c|}{ Included in parasitic heat use } & Assumption \\
\hline Labour need & 4 & 4 & 4 & $\begin{array}{l}\text { Human } \\
\text { hours/day }\end{array}$ & Assumption \\
\hline Labour wage & 10 & 10 & 10 & EUR/h & Assumption \\
\hline Leftover digestate & 16607 & 18789 & 16876 & t/year & Calculations \\
\hline $\begin{array}{l}\text { Desulphurization } \\
\text { compressor }\end{array}$ & 100000 & 100000 & 100000 & EUR/unit & [19] \\
\hline $\begin{array}{l}\text { Desulphurization } \\
\text { compressor life span }\end{array}$ & 10 & 10 & 10 & Years & [19] \\
\hline Electricity usage & \multicolumn{4}{|c|}{ Included in parasitic electricity use } & Assumption \\
\hline $\begin{array}{l}\text { CHP unit electrical } \\
\text { capacity }\end{array}$ & 250 & 250 & 250 & $\mathrm{~kW}$ & Assumption \\
\hline Produced electricity & 2190 & 2190 & 2190 & MWh/year & Calculations \\
\hline Produced heat & 3942 & 3942 & 3942 & MWh/year & Calculations \\
\hline Parasitic electricity usage & $7 \%$ & $7 \%$ & $7 \%$ & $\%$ of production & [19] \\
\hline Parasitic heat usage & $30 \%$ & $30 \%$ & $30 \%$ & $\%$ of production & [19] \\
\hline $\begin{array}{l}\text { Feed in electricity sales } \\
\text { tariff }\end{array}$ & 142.05 & 142.05 & 142.05 & EUR/MWh & {$[20]$} \\
\hline Electricity sales tariff & 33.37 & 33.37 & 33.37 & EUR/MWh & [20] \\
\hline Heat sales tariff & 54.55 & 54.55 & 54.55 & EUR/MWh & [19] \\
\hline Digestate sales tariff & 9 & 9 & 9 & EUR/t & [19] \\
\hline \multicolumn{6}{|l|}{ Additional inputs } \\
\hline Inflation rate & $2 \%$ & $2 \%$ & $2 \%$ & $\%$ & [20] \\
\hline Rate on loan & $3.5 \%$ & $3.5 \%$ & $3.5 \%$ & $\%$ & [19] \\
\hline $\begin{array}{l}\text { Loan amount of total } \\
\text { investment }\end{array}$ & $70 \%$ & $70 \%$ & $70 \%$ & $\%$ & [19] \\
\hline Loan time & 10 & 10 & 10 & Years & [19] \\
\hline Income tax & $15 \%$ & $15 \%$ & $15 \%$ & $\%$ & [19] \\
\hline
\end{tabular}

\section{REFERENCES}

[1] Elegbede I., Guerrero C. Algae biofuel in the Nigerian energy context. Environmental and Climate Technologies 2016:17(1):44-60. doi:10.1515/rtuect-2016-0005

[2] Kelly M. S., Dworjanyn S. The potential of marine biomass for anaerobic biogas production: a feasibility study with recommendations for further research. UK: The crown estate, 2008. 
[3] Matemilola S., Elegbede I. O., Kies F., Yusuf G. A., Yangni G. N., Garba I. An Analysis of the Impacts of Bioenergy Development on Food Security in Nigeria: Challenges and Prospects. Environmental and Climate Technologies, 2019:23(1):64-83. doi:10.2478/rtuect-2019-0005

[4] Chiaramonti D., Prussi M., Buffi M., Casini D., Rizzo A. Thermochemical conversion of microalgae: Challenges and opportunities. Energy Procedia 2015:75:819-826. doi:10.1016/j.egypro.2015.07.142

[5] Balina K., Romagnoli F., Pastare L., Blumberga D. Use of macroalgae for bioenergy production in Latvia: review on potential availability of marine coastline species. Energy Procedia 2017:113:403-410. doi:10.1016/j.egypro.2017.04.022

[6] Chia S. R., et al. Sustainable approaches for algae utilization in bioenergy production. Renewable energy 2018:129(B):838-852. doi:10.1016/j.renene.2017.04.001

[7] Pastare L., Romagnoli F., Rugele K., Dzene I., Blumberga D. Biochemical methane potential from anaerobic digestion of the macrophyte Cerathophyllum demersum: a batch test study for Latvian conditions. Energy Procedia 2015:72:310-316. doi:10.1016/j.egypro.2015.06.045

[8] Sabunas A., Romagnoli F., Pastare L., Balina K. Laboratory algae cultivation and BMP test with Ulva intestinalis from the Gulf of Riga. Energy Procedia 2017:113:227-284. doi:10.1016/j.egypro.2017.04.066

[9] Romagnoli F., Pastare L., Sabunas A., Balina K., Blumberga D. Effects of pre-treatment on Biochemical Methane Potential (BMP) testing using Baltic Sea Fucus vesiculosus feedstock. Biomass and Bioenergy 2017:105:23-31. doi:10.1016/j.biombioe.2017.06.013

[10] Graham S., Eastwick C., Snape C., Quick W. Degradation of biomass fuels during artificial storage in laboratory environment. International Journal of Low-Carbon Technologies 2012:7(2):113-119. doi:10.1093/ijlct/cts029

[11] Central Statistical Bureau of Latvia. The average air temperature monthly.

[12] Sustainable Energy Ireland. A review of the potential of marine algae as a source of biofuel in Ireland. Dublin: SEI, 2009.

[13] Hagenkamp-Korth F., Ohl S., Hartung E. Effects on the biogas and methane production of cattle manure treated with urease inhibitor. Biomass and Bioenergy 2015:75:75-82. doi:10.1016/j.biombioe.2015.02.014

[14] Holden J. J., Kingzett B. C., MacNeill S., Smith W., Juanes F., Dudas S. E. Beach-cast biomass and commercial harvesting of non-indigenous seaweed, Mazzaella japnocia, on the east coast of Vancouver, British Columbia. Journal of Applied Phycology 2018:30(2):1175-1184. doi:10.1007/s10811-017-1321-1

[15] Dhanushkodi S., Wilson V. H., Sudhakar K. Life cycle cost of solar biomass hybrid dryer systems for cashew drying of nuts in India. Environmental and Climate Technologies 2015:15(1):22-33. doi:10.1515/rtuect-2015$\underline{0003}$

[16] Dhilon B. S. Life Cycle Costing for engineers. US: CRC Press, 2009.

[17] Ekodoma SIA. Informative material for biogas project developers in Latvia about licensing and financial procedures [Online]. [Accessed 04.12.2018]. Available: http://www.biogasin.org/files/pdf/WP3/D.3.8.5_EKODOMA_LV.pdf

[18] van Djik W., van der Schoot J. R. Public output report of the EnAlgae project: An economical model for offshore cultivation of macroalgae. Swensea, 2015.

[19] Krastina J., Romagnoli F., Balina K. SWOT analysis for a further LCCA-based techno-economic feasibility of a biogas system using seaweeds feedstock. Energy Procedia 2017:128:491-496. doi:10.1016/j.egypro.2017.09.065

[20] Ministry of Economics. Methodological guidelines of IRR calculations in order to decrease overcompensation for merchants selling electricity in the mandatory procurement program. Riga, 2016

[21] Mankiw N. G. Principles of macroeconomics Cengage Learning. US: South Western College Pub, 2014.

[22] Fabrycky W. J., Blanchard B. S. Life-cycle cost and economic analysis. Englewood Cliffs: Prentice Hall, 1991.

[23] Asiedu Y., Gu P. Product life cycle cost analysis: state of the art review. International Journal of Production Research 1998:36:883-908. doi:10.1080/002075498193444

[24] Reidy R., Davis M., Coony R., Gould S., Mann C., Sewak B. Guidelines for life cycle costs analysis. Stanford: Stanford University, 2015.

[25] Potkany M., Hitka M., Krajcirova L. Life Cycle Cost Calculation at the transport company in the supply of production of wooden houses - Case study. MATEC Web of conferences 2017:134:00049. doi:10.1051/matecconf/201713400049

[26] Skid steer pricing [Online]. [Accessed 28.08.2018]. Available: https://www.alibaba.com/product-detail/ChineseBobcat-700kg-mini-skid-steer_60756404107.html?spm=a2700.7724838.2017115.72.6def 6d98He0jUZ

[27] Central Statistical Bureau of Latvia. Average prices of energy resources for end-user (value added tax exempt).

[28] Boat rental pricing [Online]. [Accessed 28.08.2018]. Available: https://www.ss.com/msg/lv/transport/transports-rent/freight-of-water-transport/blhpgl.html

[29] Truck rental pricing tool [Online]. [Accessed 28.08.2018]. Available: http://www.storent.com/lv/EquipmentCatalog /Equipment Catalog.aspx ?open=2\&itemNumber=1bc23f56-ef184457-9533-317b7025ca30\&n ame=Kravas\%20mašīna, \%20pašizgāzējs, \%2012m3

[30] Freshwater and affluent pricing [Online]. [Accessed 28.08.2018]. Available: https://www.rigasudens.lv/pakalpojumi/ tarifi-un-cenas/ 